advantages of their forethought and prescience; and those countries which, content with ancient prestige and former prowess, have neglected their duty to higher learning and have left their universities to languish on the doles of patriotic benefactors will sink into subsidiary places, and their part for the future will be to serve the men of brains with whom they have had to contend on such unequal terms.

\section{SCIENCE AND THE EMPIRE.}

I $\mathrm{T}$ was a happy idea which resulted in the association of the British Empire League and the British Science Guild to pay honour to the Colonial Prime Ministy during their visit to this country. The cooperalon of men of science with statesmen whose special work is to govern and develop the constituent pafts of the Empire can result in nothing but increased national efficiency, and the presence of Sir Wilfrid Laurier, Mr. Deakin, Sir Joseph Ward, Sir William Lyne, Mr. F. R. Moor, and Mr. T. Bent at the banquet held on May 2 is a gratifying sign that the need for applying the methods of science to affairs of State becomes year by year more fully recognised. The banquet provided the only opportunity the Prime Ministers have had of meeting men of science and others interested in the progress of knowledge and desirous of introducing the scientific spirit into the administration of Imperial affairs.

Lord Derby occupied the chair at the banquet, and about 260 guests were present, including many men of science and distinguished representatives of the Imperial service and administration, and of law, art, and other departments of intellectual activity. Mr. Haldane, who was to have represented the united interests of the British Empire League and the British Science Guild, was, unfortunately, unable to be present; and his place was taken by the Vice-Chancellor of the University of Oxford, Mr. T. H. Warren, who, in supporting the toast of "Our Guests," proposed by Lord Derby, referred to the relation of universities to the Empire and national progress as follows :- -

Why do the universities and the educational interests wish to add their greeting to those which have been pressed, I am afraid, in overwhelming and almost surfeiting measure, on tho distiyguished men who have crossed the ocean to visit ulf $P$ assure them that no welcome can be more warns out hay not jough. I think it is because we feel that to the instinctive and intuitive welcome which has manifesled itself so spontanebusly from every portion of English society we have some little to add. We feel that learning and science have something to say to Empire. We feel that, more and more, nowadays scientific training and thorough study of history, of the science of history and of sociology, is necessary to the proper carrying out of every great enterprise, and that Empire is one of the greatest enterprises on which man, intrepid man, has advanced. The student of history sees, or thinks he sees, a development, an evolution in the political as in the animal kingdom. The family, the clan, the city, the kingdom, the Empire, as they unravel themselves in the long series of sequences, need a corresponding advance in trained and educated intelligence. Now, we in our universities, and in the learned societies study these questions in the abstract. It is our duty and privilege in the insulated detachment, in the clear and calm life of academic tranquillity, to study these problems, and to try to find the solution of them; to study economic problems apart from the bias and prejudices of party and of commercial interest, and to study science in that spirit of disinterested devotion which, after all, I think Sir Norman Lockyer will agree with me, in the long run has the promise of this world, and, in a sense, of the otherof the world alike of truth and the world of success. But universities have now, not only an abstract, but a personal No. 1958 , VOL. 76$]$ part to play. It is their privilege to bring together, and their duty to bring together, the brightest minds, at the most impressionable age, of those who will be in the future the leaders, whether in thought or in action, of the Empire. The university has had in the past a great part in bringing our leading men together in their early days and giving them common sentiment and common loyalty and knowledge of each other. May it not be so still more in the future on a wider scale and in a wider way? I hope that the universities, and the learned societies, and the educational establishments of this country feel, I believe I can say they do feel, that they have new and extended duties. Already Oxford and Cambridge, and the old universities of which I have spoken, realise that they are not only universities of a kingdom, but universities of an Empire. In future, no doubt, other universities of the Empire more and more will play their part-the universities of Montreal, of Melbourne, of Sydney; of New Zealand,. and of the Cape. They, too, will have their traditions and their opportunities. There will be special opportunities of science and of learning, a special atmosphere and special surroundings in one place more than another, and I look forward to the time when students and professors will pass to and from one university to another. Meanwhile, let us make the beginnings, let us attack at once this great future which lies before us, let us take those steps which are now possible and promising. Let us use every opportunity of getting to know and to understand each other, and then I think that this great gathering of 1907 will prove not less fruitful in the scientific, and in the learned, and in the academic, than it has proved and is proving in the political and social sphere.

The toast was responded to by Sir Wilfrid Laurier, the Hon. Alfred Deakin, and Sir Joseph Ward. In the course of his remarks, Mr. Deakin said :-

Of all the meetings which we have been able to attend this has perhaps the most distinctive character. Never before in my experience have we seen blended the two sections of an Eppire/League of patriotism united to a body of scientife mon yhose immense abilities, whose sterling achievelynte the pride of the last century and the promise of this, and who are content to descend from those exalted heights, in which they unravel the mysteries of the universe, to find themselves perplexed by the truisms of politics. And if, as has been suggested, this union be typical, surely it is most fortunate, and certainly most necessary. If there is anything on this earth in human action which is casual and empirical, which is go-as-you-please and happy-go-lucky, it is the British Empire. Exactly how it came to be, precisely what it is, and what on earth it is going to be, no scientific prophet can tell. On the other hand, we have the men of science, calm and luminous, rigid and regular-I mean in their professional studies-aiming above all things at method, at principle, at organisation, the last three things we seem incapable of introducing into our Empire. . And yet, though imperceptible, though unchangeable, there are manifest forces of cohesion, which even thei finest instruments cannot measure, which keep this Empire as an Empire together. There are a series of rudimentary, of imperfect, of catch-as-catch-can organisations, by means of which, in some mysterious manner, this unwieldy, this gigantic and inexplicable combination, manages to survive. Surely we shall yet be found willing to sit at the feet of our scientific teachers and to endeavour, at all events at the outset, to acquire that knowledge in scientific manner, and by scientific methods, which shall enable us to appreciate, in the first place, the vast, the incalculable natural resources which are at present in our possession under the Flag-the means of utilising these instruments of material power for the benefit of our race. That appears to me to be the task of Empire, the task of scientific conquest of its physical, and shall we not be bold and say, ultimately of its political problems? The Empire rests upon the individual citizen - the individual citizen that has great capacity for service, providing you permit him to have access to these means of knowledge, to that stored-up wisdom of the ages, to these lessons and teachings which science can place in our hands. By these 
means we annihilate distance and draw the Empire together. By these means we enable them to conquer the wilderness and still carry with them the necessities of civilisation. By these means, in the tiniest hamlet, we plant almost first the schoolhouse to which the children go, and, when the principle of a scientific system of education is really in practice, the Empire will be marching indeed. Therefore I hail to-night, sir, the presence here of the intellectual men who are representatives of the scientific movement, and their blending with the British Empire League I take as one of the happiest auguries of our future.

\section{NOTES.}

THE managers of the Royal Institution have awarded the Actonian prize of one hundred guineas to Madame Curie, as the author of the essay "Recherches sur les Substances Ray \%actives."

Sir William Ramsay, K.C.B., F.R.S., has been elected an honorary mp hber of the Academy of Sciences of Christiania; ard the Società italiana delle Scienze (known as the Society the Forty) has conferred upon him the Matteucci gold/medal for 1907 .

THE North Sea Investigation Commissioners will be entertained by thy Corporation at the Guildhall on Friday, June 14, the ford Mayor presiding. The Fishmongers' Company will give a dinner in their honour on the previous evening at Fis/mongers' Hall.

THE Government of Chili has appointed Count de Montessus de Ballore, of Abbeville, France, to institute a seismological vice of the first rank. This action on the part of th Chilian Government is, says Science, a direct result of the disastrous Valparaiso earthquake of last August. The service in question will, at the beginning, inclde one station of the first rank and threc of the second.

Prof. Ira Remsen, president of the Johns Hopkins University, has been elected president of the National Academy of Sciences, in succession to Mr. Alexander Agassiz. The vafncy thus created in the vice-presidency has been filled the election of Dr. C. D. Walcott, secretary of the Smithsonian Institution. Sir James Dewar, F.R.S., Prof. A. R. Forsyth, F.R.S., Prof. D. Hilbert (Göttingen), and Prof. J. C. Kapteyn (Gröningen) have been elected foreign associates of the academy.

THE University of Geneva will celebrate with appropriate pomp and circumstance the $35^{\text {oth }}$ anniversary of its foundation, which falls in 1909. We learn from the British Medical fournal that a committee has been appointed to ar ange for the proper solemnisation of the festal rites, to which representatives of foreign universities will be invited. The "Academy," founded by John Calvin in 1559 , retained that title until 1798 . It was afterwards erected into a university, and reached its full development, with faculties of theology, law, physic, philosophy, and science, in 1873 .

REuTER reports that the Observatory of Catania and Etna has issued the following statement:- "The activity of Mount Etna is jreasing. The mouth at the base of the central crater ifemitting vapour and small incandescent stones. On $\mathrm{Mg}_{4}$, at ri.ro a.m., another mouth of smaller dimensiong opened and threw up boiling lava. At the observatory the sound of an almost continuous eruption has been heard up to May 6 . At Nicolosi a reddish vapour was seen rising from the volcano."

THE professors of the National Museum of Natural History of Paris ho decided to open an international subscription with object of offering a worthy tribute No. I 958, NoI. 76] to the memory of Lamarck, by erecting his statue in the Jardin des Plantes. Subscriptions may be sent to Prof. Joubin, at the National Museum of Natural History, Paris. The committee has decided to offer to all subscribers of not less than twenty francs a reproduction in heliogravure of an authentic unpublished portrait of Lamarck, which was painted for his family by Thévenin in 1801. To all subscribers of not less than 200 francs a plaster cast of the bust of Lamarck by the sculptor Fagel (to whom is entrusted the execution of the proposed monument) will be presented. The scheme has already received distinguished support, and a comprehensive committee comprising representative men of science of all nationalities has been formed. Among the list of the committee we notice the names of Sir John Evans, K.C.B., Sir Archibald Geikie, Prof. Ray Lankester, and Sir John Murray, K.C.B.

THE New York Academy of Sciences will celebrate on May 23 the 20oth anniversary of the birth of Linnæus. The anniversary celebrations will begin at the American Museum of Natural History. with an exhibition of American animals known 8 Linnæus. Letters concerning the anniversary rece from scientific societies will be read at the beginning of the morning session, and afterwards an address on North American geography in the time of Linnæus will be delivered by the president of the American Geographical Society. Dr. J. A. Allen has been invited to speak on Linnæus and American zoology. In the afternoon there will be an exhibition of American plants known to the Swedish naturalist, and an address on Linnæus and American botany wil! be given by Dr. Per Axel Rydberg. A bronze tablet in memory of Linnæus, a gift to New York from the Academy of Sciences, will be unveiled at the bridge-which is to be dedicated to Linnæus-over the Bronx River in Pelham Parkway, between the Botanical Garden and the Zoological Park. Numerous addresses will be delivered in connection with the unveiling ceremony. In the evening, at the museum, the director of the museum of the Brooklyn Institute will deliver an address on Linnæus and American natural history. The various meetings will be open to the public.

WE have to acknowledge the receipt of a copy of the first part of a memoir on the caterpillars of French Lepidoptera " I P Premiefs des Lépidoptères Français"), by/Prof. (C. A. Mitunnet, of the College of Natural Scienc at Dizier. The memoir is being published in the ires of the Society of Letters, Sciences, \&c., of St. Dizier, the first part, which deals with the caterpillars of butterflies, being dated I906. Unfortunately, there are no illustrations.

In a report on Antarctic birds collected by the Scotia Expedition contributed to the Ibis for April, Mr. Eagle Clarke has added four species--the Arctic tern, the blue petrel, the short-winged petrel, and Hutton's sooty albatross - to the nine previously recorded from within the Antarctic circle. Petrels and their relatives are attracted, it is suggest so far south by the extraordinary abundance of food be found immediately north of the ice-barrier, some of these visitors making their appearance in autumn after the breeding season, while others may be non-breeding birds which spend the whole summer in the South Antarctic. That the Arctic tern, after breeding in the far north, should visit the opposite pole is a most remarkable fact.

IN reference to a suggestion that Fair Island, an outlying member of the Shetland group, is specially favoured by migratory birds, $y$. Eagle Clarke, in a paper pub- 